\title{
The conservation status in 1982 of the Aldabra White-throated Rail Dryolimnas cuvieri aldabranus
}

\author{
N. J. COLLAR
}

\section{Summary}

The Aldabra White-throated Rail Dryolimnas cuvieri aldabranus is confined to Middle Island (c. 7,700 birds), Ile Polymnie (c. 270) and Ile aux Cèdres (c. 80) on Aldabra Atoll (now a World Heritage Site) in the Seychelles. It uses all available terrestrial habitats, but chiefly occurs in scrub cover and particularly in the densest types, where leaf-litter (and hence litter fauna) is richest. Its extinction on Assumption, Astove and Cosmoledo is attributable to widespread habitat loss and disturbance, and to human utilization as food; the extent to which rats and cats affect the form, which is flightless, is debatable.

\section{Introduction}

The Aldabra White-throated Rail Dryolimnas cuvieri aldabranus, restricted to the Indian Ocean atoll of Aldabra in the Republic of Seychelles, was identified as threatened in the second edition of the ICBP Red Data Book (King 1978-1979). In $1981 \mathrm{I}$ assumed responsibility for the compilation of the third edition and, as evidence of progress for the ICBP World Conference in August 1982, I issued draft accounts of 28 East African and Indian Ocean species and subspecies, including one for the Aldabra Rail, in a thin ring-bound booklet (Collar 1982), of which about 50 were produced and distributed without charge, a few copies going to libraries.

Publication of Collar and Stuart (1985) rendered most of this booklet obsolete, and it is now virtually unobtainable. However, Collar and Stuart took the decision to exclude subspecies, so the material in the booklet on five island races in the Seychelles (although summarized and updated - the rail under an erroneous subspecific name - in Appendix F of Collar and Stuart 1985) has not been superseded by a fuller ICBP/BirdLife treatment. The account of the Aldabra Rail has particularly remained relevant because it contains significant material from an unpublished text by Huxley (1982). When the paper by Hambler et al. (1993) was submitted to Bird Conservation International, a referee's report suggested that since Collar (1982) was cited so often and appeared to be so inaccessible it would make sense to publish the appropriate part of it in conjunction with the paper under review.

A version of my text on the Aldabra Rail therefore appears below, almost exactly as referred to by Hambler et al. (1993). The only changes I have made are to replace the summary, to improve the English at a few places, to add 
some sentences and references that clarify meaning and explain the modern status of Aldabra, and to rearrange what were large continuous sections of text into paragraphs and under subheadings. The three places where the text has been updated are marked in square brackets and are in any case identifiable by the post-1982 references used. It is, however, worth noting that there is considerably more information in the sources used, notably on ecology (including breeding), than this early compilation properly reflects.

\section{Distribution}

\section{Aldabra}

On Aldabra, there is no firm evidence that the species ever occurred on much the largest land-mass, South Island (Grande Terre), but it has been recorded from all other main islands (Middle Island, Ile Polymnie and West Island) and the larger minor ones (Ile aux Cèdres, Ile Michel and Ile Esprit) (Ridgway 1896, Fryer 1911, Vesey-Fitzgerald 1940, Benson and Penny 1971, Penny and Diamond 1971; see map in Hambler et al. 1993, following paper in this issue). It now survives on Middle Island (Ile Malabar), Ile Polymnie and Ile aux Cèdres.

The population on West (Ile Picard) appears always to have been low and never away from the Settlement; there are no positive references to its presence there after 1908 and it was accepted as extinct by 1967 (Gaymer 1967, Huxley 1982). The population on Esprit died out before 1960; that on Michel between June 1972 and December 1973 (Huxley 1982). The early reports explain the rail's absence from South Island through the action of cats (Ridgway 1896, Fryer 1911) but it may be that the species never naturally occurred there (Huxley 1982): it is now known that Seychellois working on the atoll commonly transported rails (which are exceptionally tame and easy to keep) to inhabited areas as pets and for food, and the populations on Esprit, Michel and West may all have resulted from human agency, with extinctions occurring naturally on the first two and through human exploitation and predation by domestic (not feral) cats on West (Huxley 1982).

Between August 1973 and April $19766 \mathrm{~km}^{2}$ of land comprising those parts of South Island closest to Ile aux Cèdres (100 $\mathrm{m}$ distant at low water) and Middle Island (200 $\mathrm{m}$ distant at low water) were thoroughly searched for rails without success, and the species's failure to colonize them through natural dispersal suggests a reluctance to swim and/or a susceptibility to sharks which lessens the likelihood of a natural presence on the more distant lagoon islands (Huxley 1982, C. R. Huxley verbally 1982).

\section{Other atolls}

There is evidence, accepted here (see Remarks), that the (probably) extinct rails of three smaller atolls near Aldabra were insufficiently distinct from $D$. c. aldabranus to warrant subspecific recognition under the name abbotti (Huxley 1982). In fact, specimens of "abbotti" are only known from one atoll and the systematic identity of the other populations is unclear. 
Assumption The form "abbotti" was collected on Assumption in 1892 (Ridgway 1896) and in the middle of the first decade this century was unanimously reported very common there (Nicoll 1906, Meade-Waldo 1908; also Stoddart 1971a), yet it was extinct by 1937 (Vesey-Fitzgerald 1940, Stoddart et al. 1970).

Astove A rail evidently this species was reported from Astove in 1836 (Stoddart 1971a), 1878 (Diamond 1981) and 1892 (Ridgway 1896), claimed extinct in 1906 (Dupont 1907) and seen by a scientist for the first and last time in 1908, when it was judged the same as the bird on Assumption (Fryer 1911); thereafter it has not been reported (Vesey-Fitzgerald 1940, Benson 1970b).

Cosmoledo Rails are presumed to have been present on Cosmoledo in 1878 (Diamond 1981), were reportedly common there in 1892 (Ridgway 1896), and reportedly present on South Island in 1908, when they were expected to be $D$. c. "abbotti" (Fryer 1911), but were declared extinct by 1937 (Vesey-Fitzgerald 1940). Nevertheless, despite never having been recorded first-hand by a reliable authority, it is on the unvisited South Island of Cosmoledo that rails may survive other than on Aldabra (Benson 1970a): guano-mining, plantations and general widespread disturbance have completely destroyed the original environments on the rest of the atoll and on the other two (i.e. Assumption and Astove) (Stoddart 1967, C. W. Benson verbally 1982). [However, no evidence for the survival of rails was found on South Island in 1982 by Mortimer (1984).]

\section{Population (Aldabra)}

Early reports of relative abundance (Ridgway 1896 , Voeltzkow 1897) or scarcity (Nicoll 1906, Vesey-Fitzgerald 1940) apparently reflect observer/locality bias rather than any major population changes. However, even recent estimates have shown substantial variation.

In 1966 the Aldabra Rail was described as "rather rare", with "only a few hundred birds" (Gaymer 1966), whereas in 1971 extrapolation from data acknowledged to be inadequate allowed a tentative estimate of at least 1,000 birds on Middle Island, with proportionately much fewer expected on the far smaller other islands (Penny and Diamond 1971). However, it is now known that the study areas on which this estimate was based were in less suitable habitat and that the measurements of one were accidentally transposed from feet into metres (Huxley 1982).

Intensive studies, 1973-1976, involving censusing of colour-marked birds, determination of several territory sizes, and song playback sampling along fixed routes, yielded estimates of 7,708 rails on Middle Island, 270 on Polymnie, and 80 on Ile aux Cèdres, giving a total of 8,058 : thus a population between 7,000 and 9,000 can be assumed (Huxley 1982).

\section{Ecology}

The Aldabra Rail utilizes all available terrestrial habitats inside its range on Aldabra, including mangroves and other intertidal zones, sandy beaches and grass patches, but chiefly open mixed scrub (on the north coasts of both Middle 
Island and Ile Polymnie), dense mixed scrub (in patches on both islands), and dense Pemphis acidula scrub (covering up to $90 \%$ of the land area on Middle, though less on Polymnie) (Huxley 1982). On Middle Island, 1973-1974, the greatest density of rails was in dense mixed scrub (one territory every $70 \mathrm{~m}$ along transects), somewhat less in dense Pemphis scrub (one territory every $87 \mathrm{~m}$ ), and much the least in open mixed scrub (one territory every $120 \mathrm{~m}$ ); on Polymnie, respective densities were lower (Huxley 1982).

These densities appear positively correlated with the abundance of leaf-litter, which is richest in dense scrub and sparsest in open mixed scrub (Huxley 1982): although the birds are highly opportunistic feeders, taking eggs and larvae of various insects, tortoise ectoparasites, marine invertebrates, (when able) skinks, geckos and land-crabs, and (when available) hatchling tortoises and turtles (Penny and Diamond 1971, Frith 1977, Huxley 1979, 1982), for most of the population soil and litter invertebrates constitute the bulk of the diet, and indeed breeding is evidently timed to coincide with the seasonal increase in litter fauna (Huxley 1982).

\section{Threats}

Extinction on Assumption was attributed to "catching for food, destruction of habitat, and predation by introduced cats and rats" (Stoddart et al. 1970), and cats were largely believed to be responsible for disappearances from West and South Islands, Aldabra (Ridgway 1896, Fryer 1911, Benson 1967, Penny and Diamond 1971).

Rats Fears concerning the threat posed by rats (e.g. Nicoll 1908) appear groundless, since fairly large populations have long existed on Ile Polymnie and Middle Island without affecting the rails (Penny and Diamond 1971): nests and chicks are rarely left unguarded and, in all cases where a rat was seen to approach either, it was successfully (and vigorously) driven off (Huxley 1982; see also Frith 1977).

Cats Although cats would appear to be very probable predators of rails, Huxley (1982 and verbally 1982) makes the following points:

(a) if cats came to Aldabra first in 1890 (Stoddart 1971b), it seems unlikely they could have wiped out all rails on much the largest island by 1892, as reported (Ridgway 1896 ), especially when no cats were seen there during a lengthy stay in 1895 (Voeltzkow 1897);

(b) cats have been present on Middle Island since 1967 (Stoddart 1971b) and probably much longer, are known from both ends of the island and may therefore occur throughout, appear to be breeding (different-sized footprints together), but must be low in number (since many lame and blind rats are present) and have made no detectable impact on intensively studied rail populations;

(c) in the only witnessed encounter between cat and rail, the rail closely followed the (apparently indifferent) cat in an aggressive posture for $30-40 \mathrm{~m}$ (A. D. Forbes-Watson in Huxley 1982); 
(d) adult rails, as long known (Ridgway 1896), are not wholly flightless and can flutter up to perches;

(e) the predominant dense scrub on Middle Island, though good for rails, appears to be difficult terrain for predators the size of cats;

(f) the seasonal scarcity of fresh water would seem likely to influence cat numbers adversely.

\section{Conservation measures taken}

Proposals to develop Aldabra as a military airbase were dropped in 1967 (Stoddart 1968). The Royal Society of London took over the lease and opened a research station there in 1971 (Stoddart 1979), which since 31 March 1980 has been controlled by the Seychelles Islands Foundation. The island was gazetted as a nature reserve on 16 June 1980, and the Seychelles government nominated it for scheduling as a World Heritage Site in 1982 (L. U. Mole in litt. 1982). [In September 1981 it became a Special Reserve and in December 1982 it was accepted as a World Heritage Site (Stoddart and Ferrari 1983).]

Cats are being killed whenever possible (Stoddart 1971b). [However, complete eradication, although desirable, appears currently unachievable (Seabrook 1990).]

\section{Conservation measures proposed}

A few pairs should be taken to establish a captive breeding colony as a reserve stock (Penny and Diamond 1971, Huxley 1982); birds held captive on Aldabra for behavioural studies bred without any difficulty (C. R. Huxley verbally 1982), and thrive on any available foods (Penny and Diamond 1971, Huxley 1982, C. R. Huxley verbally 1982). Despite remarks under Ecology, attention should be given to monitoring rail and cat populations on Middle Island, and consideration given to methods of reducing cat numbers should they ever rise (Huxley 1982). The small, morphologically distinct population on lle aux Cèdres also deserves monitoring (Huxley 1982).

\section{Remarks}

A critical re-examination of five extant skins of D. c. "abbotti", undertaken in the light of knowledge of aldabranus not available to the previous reviewer (see Benson 1967), suggests that at least two characters considered distinctive of "abbotti" and two of aldabranus are actually shared (either between them and/or also with nominate cuvieri), and that the only plumage differences concern the widths of white barring below and dark streaking above, where there is in any case some overlap. In structural morphology, the only significant differences between "abbotti" and aldabranus lie in the latter being shorter-winged and longer-billed (contra assertion on tarsus length in Penny and Diamond 1971). Moreover, in terms of leg and bill size, birds from lle aux Cèdres are more distinct from the rest of aldabranus than is "abbotti". In these circumstances, separation of "abbotti" seems unwarranted, but its intermediate characters suggest that it was the parent stock from which Aldabra was colonized and, if 
flying capacity had already been reduced by that stage, this might explain why (possibly) not all the islands on Aldabra were reached (Huxley 1982).

It should be noted that this is a rare example in the avian class of ability and inability to fly within a species. Moreover, the Aldabra Rail is the last extant flightless bird in an area of the Indian Ocean renowned for them (Stoddart and Wright 1967).

\section{Acknowledgements}

I am greatly debted to C. R. Huxley for free access to his extensive unpublished typescript material; and to R. P. Prŷs-Jones and C. J. Bibby for good advice in bringing this paper to publication.

\section{References}

Benson, C. W. (1967) The birds of Aldabra and their status. Atoll Res. Bull. 118: 63-111. Benson, C. W. (1970a) Land (including shore) birds of Cosmoledo. Atoll Res. Bull. 136: $67-81$.

Benson, C. W. (1970b) Land (including shore) birds of Astove. Atoll Res. Bull. 136: 115120.

Benson, C. W. and Penny, M. J. (1971) The land birds of Aldabra. Phil. Trans. R. Soc. Lond. B.260: 529-548.

Collar, N. J. (1982) Extracts from the Red Data Book for the birds of Africa and associated islands. Cambridge, U.K.: International Council for Bird Preservation (unpublished).

Collar, N. J. and Stuart, S. N. (1985) Threatened birds of Africa and related islands: the ICBP/IUCN Red Data Book. (Third edition, part 1). Cambridge, U.K.: International Council for Bird Preservation, and International Union for Conservation of Nature and Natural Resources.

Diamond, E. P. (1981) An early report of the flora and fauna of the Aldabra group. Atoll Res. Bull. 255: 1-10.

Dupont, R. (1907) Report on a visit of investigation to St Pierre, Astove, Cosmoledo, Assumption and the Aldabra Group. Victoria, Mahé: Government Printing Office.

Frith, C. B. (1977) Life history notes on some Aldabran land birds. Atoll Res. Bull. 201.

Fryer, J. C. F. (1911) The structure and formation of Aldabra and neighbouring islands with notes on their flora and fauna. Trans. Linn. Soc. Lond. (2)14: 397-442.

Gaymer, R. (1966) Aldabra - the case for conserving this coral atoll. Oryx 8: 348-352.

Gaymer, R. (1967) Observations on the birds of Aldabra in 1964 and 1965. Atoll Res. Bull. 118: $113-125$.

Hambler, C., Newing, J. and Hambler, K. (1993) Population monitoring for the flightless rail Dryolimnas cuvieri aldabranus. Bird Conserv. Internatn. 3: 307-318.

Huxley, C. R. (1979) The tortoise and the rail. Phil. Trans. R. Soc. Lond. B.286: 225-230.

Huxley, C. R. (1982) Unpublished typescript on the Aldabra Rail.

King, W. B. (1978-1979) Red Data Book, 2: Aves. Morges, Switzerland: International Union for Conservation of Nature and Natural Resources.

Meade-Waldo, E. G. B. (1908) Abbott's Rail Rallus abbotti. Avicult. Mag. N.S. 6: 219-221.

Mortimer, J. A. (1984) Rediscovery of the turtle dove Streptopelia picturata on Cosmoledo Atoll in the Seychelles. Ibis 126: 81-82.

Nicoll, M. J. (1906) On the birds collected and observed during the voyage of the Valhalla,

R.Y.S., from November 1905 to May 1906. Ibis (8)6: 666-712.

Nicoll, M. J. (1908) Three voyages of a naturalist. London: Witherby and Co. 
Penny, M. J. and Diamond, A. W. (1971) The White-throated Rail Dryolimnas cuvieri on Aldabra. Phil. Trans. R. Soc. Lond. B. 260: 529-548.

Ridgway, R. (1896) On birds collected by Doctor W. L. Abbott in the Seychelles, Amirantes, Gloriosa, Assumption, Aldabra, and adjacent islands, with notes on habits, etc., by the collector. Proc. U.S. Natn. Mus. 18 [1895]: 509-546.

Seabrook, W. (1990) The impact of the feral cat (Felis catus) on the native avifauna of Aldabra Atoll, Seychelles. Revue Ecol. (Terre Vie) 45: 135-145.

Stoddart, D. R. (1967) Summary of the ecology of coral islands north of Madagascar (excluding Aldabra). Atoll Res. Bull. 118: 53-61.

Stoddart, D. R. (1968) The Aldabra affair. Biol. Conserv. 1: 63-69.

Stoddart, D. R. (1971a) White-throated Rail Dryolimnas cuvieri on Astove Atoll. Bull. Brit. Orn. Club 91: 145-147.

Stoddart, D. R. (1971b) Settlement, development and conservation of Aldabra. Phil. Trans. $R$. Soc. Lond. B. 260: 611-628.

Stoddart, D. R. (1979) Aldabra and the Aldabra Research Station. Phil. Trans. R. Soc. Lond. B. 286: 3-10.

Stoddart, D. R., Benson, C. W. and Peake, J. F. (1970) Ecological change and effects of phosphate mining on Assumption Island. Atoll Res. Bull. 136: 121-145.

Stoddart, D. R. and Ferrari, J. D. M. (1983) Aldabra atoll: a stunning success. Nature and Resources 19: 20-28.

Stoddart, D. R. and Wright, C. A. (1967) Geography and ecology of Aldabra Atoll. Atoll Res. Bull. 118: 11-52.

Vesey-Fitzgerald, D. (1940) The birds of the Seychelles, 1: the endemic birds. Ibis (14)4: $480-489$.

Voeltzkow, A. (1897) Einleitung: Madagaskar, Juan de Nova, Aldabra. Abhandl. Senckenb. naturf. Ges. 21: 1-76.

N. J. COLLAR

BirdLife International, Wellbrook Court, Girton Road, Cambridge CB3 oNA, U.K. 